\title{
Disappearing Worlds: Anthropology and \\ Cultural Studies in Hawai'i and the Pacific
}

Geoffrey M White and Ty K wika Tengan

$T_{1}$

hroughout most of the twentieth century, western audiences took for granted the role of anthropology as the field through which indigenous societies were studied and represented in scholarly literature. In recent decades this role has taken on an increasingly public and self-conscious posture. Long before the recent controversy over work among the Yanomami peoples of the Amazon basin (Tierney 2000), for example, the writings of Margaret Mead on S moa had become a focus for professional and popular debate (Freeman 1983) - a debate that transgressed boundaries between communities of indigenous peoples and the circles of professional anthropology. In this paper, we examine these shifting disciplinary politics through a reflection on anthropological practice in the Pacific Islands region, particularly our own home, Hawai'i. We limit ourselves to discussion of cultural anthropology, although equally complex and contentious politics surround archaeology and biological anthropology in the Pacific.

The larger context for the increasingly public and political posture of anthropology is the process of decolonization that has been unfolding throughout the late twentieth century, often radically transforming the communities where "classical" anthropological research is conducted (Asad 1979). As the social and political contexts for anthropology have been transformed, so has the academic landscape where new paradigms and institutional locations for cultural study continue to emerge. In this paper we take advantage of these developments to critically examine the construction of anthropology through its practice in the Pacific and through its relations with the emerging fields of cultural studies and native studies - two fields conjoined in the title of this special issue of The Contemporary Pacific: Native Pacific Cultural Studies on the Edge. ${ }^{1}$

The Contemporary Pacific, Volume 13, Number 2, Fall 200I, 38I-4I6

(C) 200 I by University of Hawai'i Press 
Our reasons for focusing on the Pacific Islands region are more than convenience. We argue that academic work in any particular locale is critically shaped by the specific histories, politics, and economics of that region. Leaving aside the problem of comparing a field as porous and heterogeneous as cultural studies with a discipline as institutionalized and bounded as anthropology (Dominguez I996), the terms of engagement with distinct styles of research necessarily depend on historical and geopolitical context, on the nature of (post)colonial states, and on the conditions and politics of fieldwork and publication. It is difficult if not impossible to generalize about these subjects without referring to specific locations, histories, and technologies. We speculate briefly about some of the dimensions of this variation across the Pacific, but our primary focus is the situation of anthropology in Hawai'i.

Our approach to these issues brings together two distinct perspectives: that of a white American anthropologist who began fieldwork in the Solomon Islands in the late I970s on the eve of national independence, and that of a Native Hawaiian or Kanaka ' iwi anthropologist embarking on long-term research in Hawai'i. ${ }^{2}$ We begin by drawing attention to absences: to the absence of Pacific Islanders and, specifically, of Hawaiians as authors, agents, and practitioners of anthropology. We are, of course, not the first to observe such absences. Twenty-five years ago, Epeli Hau'ofa, writing as one of the first Pacific Islander anthropologists, noted that "after so many years of involvement, we have produced only one native anthropologist, the late Dr Rusiate Nayacakalou. ... So far our concern in this direction has been to involve Pacific peoples in our research projects only in the capacity of field assistants" (I975a, 287-288). Hau'ofa also foresaw the consequences of such absences when he continued, "the longer that we, as outsiders, monopolise the research in the region, the stronger will be the feelings against us, and the more difficult will be our task of extricating our discipline from the taint of imperialism and exploitation." ${ }^{3}$ Some years later Faye Harrison made very much the same point for the field as a whole in Decolonizing Anthropology: Moving Further toward an Anthropology for Liberation, calling for minority and native anthropologists to play a greater role in transforming the field (I997). ${ }^{4}$ We do not note these absences to repeat the obvious deprivations of colonial history, or to whip a simplistic caricature of anthropology-but rather to probe institutional practices that enforce and maintain boundaries of inside-out, native-other, and representer-represented in Pacific scholarship. 
One does not have to look far for signs of disturbance in the traditional premises of anthropology or, for that matter, in the conventions of scholarly and scientific research of all kinds carried out in indigenous communities. In anthropology, these unsettled conditions have for some time been the subject of critical reflection, both inside and outside the discipline (Hymes 1972). For the Pacific, examples of disciplinary disturbance crop up regularly on the internet list of the Association for Social Anthropology in Oceania. In one recent exchange, for example, discussion of the language of instruction in a new anthropology program at the University of S moa (chaired by Unasa $\mathrm{Va}^{\prime} \mathrm{a}$ ) led to a wider exchange about disciplinary aims and practices. And in late I999 a proposal was posted on that list for an "informal session" at the association's annual meeting to discuss the crisis of ethnic conflict in Solomon Islands. Soon after it was posted, however, the proposal was met with a strong challenge from a Solomon Island scholar, joined by several others, questioning the politics or propriety of such a session held with little or no involvement of Solomon Islanders. There is much that might be said about these exchanges, but we note them only briefly as evidence that the professional practices of anthropology, especially the assumptions that separate "field" and "home" and the discursive practices that separate outsider-anthropologist-author and insider-native-informant are unstable zones of contention that continue to shift and transform (Clifford I997, I989).

\section{The Pacific}

The Pacific has been one of the most desired regions for traditional anthropology, by which we mean American or European researchers doing fieldwork in small-scale nonwestern communities for scholarly or scientific purposes. The Pacific Islands have been host to fieldwork by many of the pioneers of twentieth-century anthropology, from Bronislaw Malinowski and Raymond Firth to Margaret Mead and Marshall Sahlins. The reasons are obvious. The region spans one-third of the world's surface and an even larger percentage of its (colonized) indigenous peoples. In short, it is home to an anthropological mother lode of linguistic and cultural diversitythe kind of small-scale, nonliterate societies with strong ancestral attachments to land that during much of the past century were the primary subjects of anthropological research.

At this moment, at the hinge of two centuries, it is clear that the political and discursive forces that have maintained these images of the Pacific 
during the twentieth century are increasingly disrupted by the twin processes of decolonization and globalization (Knauft 1999). The destabilization of dominant models of the Pacific is symptomatic of a wider crisis in area studies, fueled by recognition of the often arbitrary and hegemonic quality of "culture areas" and the practices that reproduce them as subjects of specialized scholarship (Rafael I994; Said I979). In this paper we draw attention to relations between an ongoing reimagining of the region as a certain kind of geocultural space and the reinvention of anthropology's disciplinary identity.

The conventional western picture of the Pacific is one of an area of a multitude of indigenous societies where both geography and culture appear as "islands" - small, bounded, and isolated. One geographer writing in the early sixties characterized the region in terms of "whole congeries of little universes, ready made isolates for study, each capable in appearance at least of being readily grasped as a whole" (Spate I963, 253). Despite their commonsense appeal, such metaphors have served to reproduce images of Pacific peoples as exotic and distant, located in geographic and cultural spaces wholly separated from the "us" of academic authorship and readership. Of course, "isolated" always only meant peripheral to European centers. And even that reading can only be perpetuated today by ignoring flows of people, culture, and capital between the Pacific, Europe, and America that intensified dramatically in the second half of the twentieth century (Hau'ofa I993).

The shifting politics and practices of cultural representation in the Pacific are challenging and transforming anthropology, as well as producing new possibilities for native studies, for cultural studies, and-reflecting the theme of this collection of papers-native cultural studies. Each of these disciplinary domains faces distinct but overlapping political and intellectual constraints. Our main focus here is anthropology in the Pacific and the struggles around anthropology's disciplinary identity that emerge in the border wars with native scholars on the one hand and with interdisciplinary cultural studies on the other.

The emergence of native Pacific authors in scholarly publishing during the latter half of the twentieth century has heightened critical awareness of the entanglement of anthropology with forces of colonization in the region. A significant number of indigenous authors concerned to represent Pacific societies in their own work have also offered critiques of the conventional practices of anthropology and history, the disciplines most involved with Pacific societies (Hau'ofa I975a; Wendt I987; Hereniko and Teaiwa I993; Trask I991; Osorio I995; Mahina I999; Smith I999). 
The criticisms of anthropology from within the culture areas where it is traditionally practiced come at the same time as the field's authority as the preeminent discipline of cultural study is eroded by new approaches in interdisciplinary cultural studies (Handler I993; Turner I993; Nugent and Shore I997). But given that cultural studies as practiced in North America and Europe has focused primarily on the literary and media productions of cosmopolitan communities, it has often seemed irrelevant to Pacific concerns with the fate of land-based (and sea-based), largely oral indigenous cultures and their struggles with colonization.

However, just as cultural studies theory and practice have been transformed as they have traveled from Britain to the United States, Australia, and now Asia (Chen I998; Hall I992; Nelson I994), they are sure to produce new travel stories as they circulate in the Pacific Islands. As theory travels it makes landfall in some places and not others. In each locale "it" is inflected differently, according to local conditions and desires. And in most cases theory only travels when people travel, enmeshing the movements of theory in the social and economic conditions of cultural production. In this paper we briefly raise questions about intraregional differences in cultural studies in the Pacific (and, for that matter, anthropology). Asking questions about regional differences is a useful way of resisting totalizing conceptions of "the Pacific" as a singular or homogenous area. Such questions also evoke comparisons that go beyond tired binaries of western or nonwestern, modern or traditional, and so forth.

While the metaphor of traveling theory is useful, it runs the risk of distracting attention from the travels of theorists, of writers, and of Pacific Islanders who have followed routes of travel, trade, and exchange for centuries (Clifford I989). One of the consequences of colonization may well be that prior networks of exchange are disrupted and often extinguished by capital economies that re-center modes of production (both economic and cultural). By dislocating indigenous practices of cultural representation (associated with regional oral histories, trade networks, and the like), the engines of western education and literacy - the tools of participation in cash economies-work to create new dichotomies of represented and represented, separating "who theorizes and who is theorized" (Diaz to White, personal communication 2000).

One of the most significant differences across the Pacific is the differential emergence of diasporic communities as Pacific Islanders have followed complex routes of migration and circulation between island homelands and metropolitan centers of the Pacific rim. The social, cultural, and economic differences associated with these transnational routes have signifi- 
cant implications for indigenous cultural production and engagement with academic and scholarly communities. Regional variations in the social, economic, and technological conditions of everyday life create dramatic differences in the conditions and possibilities for both literary and, now, electronic cultural production. At present, most of the indigenous authors who are producing scholarly work and cultural criticism are located in metropolitan communities in Fiji, Guam, Hawai' $i$, Aotearoa, and around the Pacific rim. (Our discussion concerns only the English-speaking Pacific. Neither space nor our limited knowledge permit an adequate discussion of New Caledonia and French Polynesia, which in general do not fit into the regional contrast we draw between the southwestern and the northern and eastern Pacific.)

Knowing that it is risky to generalize about geocultural regions-especially in terms that reduce easily to binary oppositions-we want to draw attention to contrasts between parts of the Pacific that are relatively more literate, mobile, and connected and those which are (relatively) more oral, fixed, and unconnected. Across the Pacific, the postwar process of decolonization has produced a set of political formations that find most independent, indigenous states located in the southwest Pacific (Melanesia) whereas the eastern and northern Pacific (roughly, "Micronesia" and "Polynesia") consist largely of colonial and quasi-autonomous states and states with indigenous minorities. Whereas the large and independent Melanesian states of Papua New Guinea, Solomon Islands, and Vanuatu are made up of mostly rural communities living on ancestral lands, most Polynesian and Micronesian states are characterized by high rates of migration to emergent urban communities in cities along the Pacific rim, such as Auckland, Honolulu, Los Angeles, and Sydney. So, for example, in the Melanesian states (where three-fourths of the population of Oceania reside), 85 percent of the population lives in rural villages. In contrast, more American Samoans now reside in Hawai'i and the US west coast than in the home islands of $S$ moa. Having taken the risk of reproducing the racist binary of Melanesian or Polynesian (and Micronesian), we note immediately, that these differential routes of movement do not imply that residents of rural Melanesian communities are either sedentary or uninvolved in indigenous modes of theorization and self-representation (Gegeo 200I), only that people of those communities are relatively less present in metropolitan institutions that generate the sorts of scholarly or literary work that enter into wider circuits of regional or global cultural production. 


\section{Roots and Routes: Anthropology and Cultural Studies}

The rise of interdisciplinary cultural studies, from its early blend of Marxism, literature, history, and sociology in Britain to its expansive presence in American English departments and communication programs, has created a foil against which cultural anthropology increasingly defines itself (Handler 1993; Turner 1993; Dominguez 1998; Peace 1998). As an interlocutor for anthropology, cultural studies has evoked various attempts at policing disciplinary borders and otherwise adjudicating what kinds of work count as valid research. We briefly note one such statement as a way of discussing one of the defining practices of anthropology-fieldwork, a practice that is also central to the identity of anthropology in the contemporary Pacific.

In an issue of The New York Review of Books (22 October 1998) Clifford Geertz wrote an essay reviewing James Clifford's book Routes: Travel and Translation in the Late Twentieth Century (1997). Oddly, it would seem, the review paired Clifford's book with an earlier ethnography of the Guayaki of Paraguay by the French anthropologist, Pierre Clastres. Although written as a book review, Geertz's article is also a reflection on the state of cultural anthropology. Reiterating what has always been a core value in anthropology, Geertz focused on the role of fieldwork as a defining feature of the field. In his view, these two books-by Clifford and Clastres-starkly frame "the value, the feasibility, the legitimacy, and thus the future of localized, long-term, close-in, vernacular field research" (69). Discussing the future of fieldwork, it turns out, amounts to a discussion of the future of the discipline of anthropology.

Significantly, fieldwork is also the subject of one of the major essays in Clifford's book. In discussing fieldwork as "spatial practice" Clifford noted the ambiguity that surrounds the concept today: "It is much less clear what counts, today, as acceptable fieldwork" ( 1997,53$)$. He went on to note issues that confront the field as it adapts to contemporary conditions, including moves to formulate projects as mobile and "multi-sited" (Marcus I995). On this point Clifford rightly questioned, "How many sites can be studied intensively before criteria of 'depth' are compromised?" ( 1997,57$)$. More important, he distinguished the political dimensions of fieldwork inscribed with "colonial, race-, class-, and genderbased definitions of center and periphery" from its character as "intensive and interactive" ( 1997,89$)$. Noting that "interactive" is "less controversial," Clifford asked, "why not simply purge the discipline's exoticist 
travel legacy while sustaining its intensive/interactive styles of research?" His answer left open the possibility of this kind of repositioning: "In a utopian mode one might argue for such a solution, and indeed things seem to be moving in this general direction" (89). In concluding Clifford wrote in disarmingly simple terms, "Sojourning somewhere else, learning a language, putting oneself in odd situations and trying to figure them out can be a good way to learn something new, simultaneously about oneself and about the places one visits" (9I).

Geertz's review essay holds up an older paradigm of anthropological fieldwork (troubled but still devoted to sustained engagement with the local) as distinct from newer cultural studies concerned with popular cultural forms that circulate through public sites and scenes. Only partly tongue-in-cheek, Geertz used Clifford's own travel metaphor (who in turn drew on the work of Paul Gilroy) to characterize this binary of anthropology and cultural studies as "roots" versus "routes." There is an uncanny resonance between these contrastive styles of cultural analysis and different forms of identity evident in the Pacific today: on the one hand, native identities based primarily in attachments to land and ancestors and, on the other, identities formed in experiences of travel, relocation, and dislocation. One reason that Pacific Islanders have been reluctant to embrace the paradigm of anthropology is precisely their interest, historically, in resisting consignment to bounded local spaces, to a depiction of "traditions" as fixed, limited, and set in opposition to modernity. As Crocombe noted in reflecting on the absence of Pacific Islanders in anthropology twenty-five years ago, "much of the fault lies with the social scientists who in many cases tend to have been backward looking. One only needs to look at the paucity of studies of Europeans or Asians in the islands, whether as officials, missionaries, academics, volunteers, businessmen, international agency staff, visiting experts, tourists" $(1975,6)$. Interestingly, the populations that Crocombe noted as missing in anthropological studies of the Pacific are precisely those who could not be easily studied on the basis of traditional modes of fieldwork.

Underpinning the mythos of fieldwork is the presumption of cultural boundary crossing, of anthropology as a practice of studying others. This aspect of anthropology (inscribed with the politics of ethnicity, nationality, and colonial history, as Clifford noted) is frequently elided with the methodological value of fieldwork. The latter typically includes recognition of the need for intensive involvement, for language competence, for the kind of broad, open-ended, and unplanned learning that comes from 
living in a community, and for the productive tension that comes from moving between the roles of member and researcher (in the language of anthropology, between participant and observer). Even if one assumes the positions of "insider" and "outsider" could be defined without presenting questions, none of these methodological aspects of fieldwork requires the ethnographer to be an outsider in terms of linguistic or cultural identity. Of course, one's identity in terms of insider-outsider positioning (rarely a simple binary) will affect the micropolitics of moving between participant and observer roles (see Narayan I993; Motzaffi-Haller 1997). Our point is that disciplinary models and practices-from fieldwork to publication -have worked historically to authorize and reinforce dichotomies that separate native subjects from anthropological agents.

\section{Anthropology AT Home}

The case of the Department of Anthropology at the University of Hawai'i provides a useful lens for examining some of the ways that boundaries between outsider-anthropologist and insider-Native have been erected and maintained through particular disciplinary practices. By reviewing briefly the history of professional cultural anthropology in Hawai' $i$, we plot shifts and developments in the field in the context of the broader history of American colonialism and hegemony. Despite numerous exceptions and qualifications, the picture that emerges is one in which research paradigms evolve in dialectic relation to the shifting structures of US colonialism. ${ }^{5}$ In recent years these same models have appeared increasingly unsettled by the politics of indigeneity associated with the movement for Hawaiian sovereignty (see Osorio, 359-379).

The discipline of anthropology at the university began in 1934 with the creation of a department chaired by Felix Keesing. A division of labor was set up between the Bernice Pauahi Bishop Museum and the university in which "Studies in problems of native adjustment to modern conditions or 'acculturation' ... . were to be the particular concern of the University [and] reconnaissance studies of native culture as it was before western culture had completely altered the past beyond recognition" were to be carried out at the museum (Luomala I969, 28). Polynesian ethnology in the "salvage" mode had been the agenda for Bishop Museum anthropologists ever since the First Pacific Science Congress, held in Honolulu in I92I, emphasized the need for anthropological research in the Pacific that studied the "rapidly disappearing native cultures" (Hiroa I945, 44). 
In Hawai'i, this project was articulated through the work of museum anthropologist E S Craighill Handy, who also served as one of the first lecturers in anthropology at the university. His collaborations with Mary Kawena Pukui led to a number of works such as The Polynesian Family

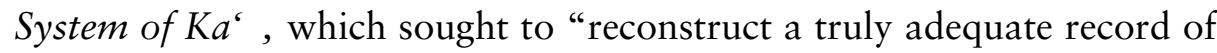
many phases of the local heritage, traditions and culture" (Handy and Pukui 1972, xvii). Though these essays and monographs contribute valuable descriptions of certain aspects of " iwi life, they also fall into the much-criticized anthropological trap of essentializing culture as timeless, static, and occurring in the past. The temporal "othering" is then elided with the spatial distancing embodied in the practice of fieldwork (Fabian I983): the appropriate or authentic objects of study may be found by traveling from the urban home base of Honolulu to the remote, rural community of $\mathrm{Ka}^{\text {‘ }}$ on the island of Hawai'i.

The absence of native authors increases the distance between the agents and the objects of anthropological research. As others have noted, the situation of the native anthropologist calls attention to tensions and contradictions in the historical definition of anthropology as the study of others (Jones I970; Narayan I993; Motzaffi-Haller 1996). Furthermore, the disciplinary value hierarchy that elevates theory over ethnography can easily relegate the native scholar and author to the role of "informant." In an early essay, Jones observed that "the native anthropologist is seen ... not as a professional who will conduct research and develop theories and generalizations, but as a person who is in a position to collect information in his own culture to which an outsider does not have access" (I970, 3I, cited in Harrison 1997,7 ).

Just this kind of marginalization seems to have occurred in the case of Mary Kawena Pukui, whose work occupies a central place in the study of Hawaiian social and cultural practices. Howard noted that credit was "misappropriated" by Handy in the account of The Polynesian Family System in $\mathrm{Ka}^{\star}$, Hawai ${ }^{\circ}$, which "was published with E S C Handy as first author, when he was primarily the scribe and she the author" (I999, 2). By I972, when the pathbreaking work Native Planters was published (Handy and Handy I972), Pukui was relegated to the status of "collaborator," even though much of the work was based on past essays and texts in which she was listed as an author (Handy and Pukui 1935; Handy and Pukui 1972; Handy, Pukui, and Livermore 1934). Howard went on to note that "this practice has been common in academic circles and conveys a great deal about western cultural imperialism, ... [ $[\mathrm{t}]$ he underlying mes- 
sage [being] that indigenous knowledge can only be legitimized and worth publishing if it bears the stamp of a western scholar" (I999). ${ }^{6}$

The colonial legacy of epidemics, Calvinist missionaries, American businessmen, Territorial plantations, and mass immigration had left anthropologists hard-pressed to find those "remnants" of Hawaiian culture that fit the traditional ethnological model of integrated, bounded traditional communities. (For comparison, we mention anthropology's neglect, until the I980s, of Christianity in the Pacific.) For many of the same reasons, those who would study racial mixing and acculturation in Hawai' $i$ found themselves in what they saw as a rich "laboratory." "The historical and present day permutations and combinations of racial stock and cultural pattern have served to transform Hawaii into one of the foremost social science laboratories of the world" (Beaglehole I937, I7).

Nor were ethnographers alone in this endeavor; physical anthropologists, sociologists, physiologists, psychologists, and other scientists received funding from a Rockefeller Foundation grant (I927-I937) to study "the mental, physical, and cultural effects of racial blending in the Hawaiian Islands" (Luomala 1969, I0). ${ }^{7}$ This project reminds us that anthropology in the Pacific, as anywhere, needs also to be understood in relation to other disciplines, primarily in the social sciences. Smith argued that "in their foundations, Western disciplines are as much implicated in each other as they are in imperialism" (I999, II). As economists, political scientists, health researchers, environmental scientists, and others-native and nonnative-increasingly ply their trades in the Pacific, the politics and value of fieldwork may take on quite a different character from that associated with anthropology projects during the twentieth century.

Felix Keesing's study of Hawaiian Homesteading on Molokai was a result of a request from the "Territorial legislature to the University for aid in analyzing homestead affairs" (1936, 8-9). His examination of "the Hawaiian rehabilitation experiment" assessed the varying degrees of success by which the Hawaiian people were overcoming the "hurdles of social readjustment" (IO8), that is, how far along they were in the process of assimilation to western standards and ideals. Moreover, his essay both reflected and reproduced a larger discourse on race that worked to disempower Kanaka ' iwi and entrench American hegemony. ${ }^{8}$

After World War Two, the gaze of university ethnography turned beyond Hawai'i to the wider Pacific. With impetus from the projects undertaken in the aftermath of the war by the Coordinated Investigation of Micronesian Anthropology (Kiste and Marshall 1999) and the larger 
growth in support for "area studies" in the postwar United States (Rafael I994), University of Hawai'i faculty and administration moved to create a center for research and study of the Pacific. ${ }^{9}$ Following recommendations of a committee headed by anthropology chair Leonard Mason, the university established the Pacific Island Studies Program (later the Center for Pacific Islands Studies) in I950 in order to coordinate the various disciplinary approaches to research in the Pacific (Quigg 1987).

Yet one group of Pacific Islanders was generally overlooked in this intensified interest in the Pacific-the Kanaka ' iwi. Between I95I and 1963, Hawaiians had virtually disappeared from the ethnographic record. Interestingly, Marion Kelly, who received the first ma in Pacific Islands Studies for her work on Hawaiian land tenure, stated, "Anthropology didn't appeal to me 'cause they didn't want to do anything about Hawai'i" (I999). Similarly, Ben Finney, who received his ma from the anthropology department in 1959 for his study "Hawaiian Surfing: A Study of Cultural Change," stated that he was discouraged from taking Hawaiian language and that "to study things Hawaiian was not prestigious" (Finney to Tengan, personal communication I999).

In contrast to these trends in the cultural anthropology of Hawaiians, archaeology and physical anthropology in Hawai'i intensified after the war. The implicit (and at times explicit) statement was that there were no Kanaka " iwi left to study; the only place to find a Hawaiian was in the ground. In simplified form, this brief history of anthropological studies in Hawai'i suggests a logical progression: from salvage ethnography of disappearing natives, to acculturation studies of Hawaiians becoming Americans, to total absence from the cultural record. Kanaka ' iwi had become too racially mixed, too acculturated and assimilated to be an object of anthropological study. This state of affairs reflects the anthropological preoccupation with the "Other": if Hawaiians were no longer culturally distinct (or exotic), they were no longer of interest to the discipline.

More important, it was precisely at this time that the United States was fortifying its position in the Pacific as the dominant world power. This policy involved securing Hawai' $i$ as a colonial outpost and rapidly militarizing the islands (Ferguson and Turnbull I998). In doing so, the United States violated United Nations procedures by removing Hawai'i from the list of non-self-governing territories by conducting a "plebiscite" that offered only statehood as an alternative to continued territorial status (M Trask I994, 80). Hawai'i's transition from territory to state was facilitated by a discourse of multiracialism - a discourse informed and legiti- 
mated by University of Hawai'i studies on racial mixture. This ideology masked underlying tensions and inequalities extant in Hawai' $i$ at the time, ${ }^{10}$ and continues today in the modern permutations of "multi-cultural paradise" (Okamura I998). The absence of Hawaiians from the ethnographic record worked to further naturalize American colonialism, making statehood seem unproblematic and desirable.

The Kanaka ' iwi did not resurface in the anthropological imaginary until the late I960s. Alarmed by the findings of a report that found Hawaiians overrepresented in nearly all categories of "social problems," members of the Lili'uokalani Trust for Hawaiian children approached the Bishop Museum and requested a research project that would serve as the basis for a preventive program of social action (Howard I974, ix). The project that resulted was coordinated by Alan Howard, a cultural anthropologist splitting time between the museum and the university's anthropology department. With support from a National Institute of Mental Health grant, Howard assembled a team of anthropologists, psychologists, educators, and graduate students to do research in the Hawaiian homestead community of $\mathrm{N} n$ kuli during the years 1965 to I968. Here, also, anthropology was one of several disciplines conducting research on Hawaiian issues. ${ }^{11}$

Rejecting the "deficiency models" prevalent in the acculturation studies, the $\mathrm{N} n$ kuli project argued that the cultural paradigms of middle-class Americans that dominated the workplace and school systems were at direct odds with those of the Kanaka ' iwi's home and community life (Gallimore and Howard I968; Howard I974). One of the most positive outcomes of the project was the Kamehameha Early Education Program (KEEP). Initiated in I970, that program used anthropological and psychological research to develop an early education program that used culturally grounded teaching methodologies for the instruction of Kanaka " iwi students. Its success in improving the performance of Hawaiian students earned it national recognition (see Boggs I985).

Despite the positive steps taken by the $\mathrm{N} n$ kuli researchers to increase involvement in the Kanaka ' iwi community, the distance between observer and observed was never successfully bridged. One of the reasons for this was the organization of fieldwork as travel, requiring entries and departures, beginnings and endings. Moving "in" and "out" of the field is inevitably circumscribed by time, such that projects end on the ground as researchers conclude the fieldwork phase of their projects. Of course, such goings and comings may be constructed in a variety of ways, depend- 
ing on the relationship between researcher and researched. In the case of $\mathrm{N} n$ kuli, there was very little follow-up work in the community once the project was concluded and reports published. Bion Griffin, current chair of the anthropology department, recalls that at a recent archaeological conference, a Hawaiian woman from $\mathrm{N} n$ kuli related how none of the anthropologists came back after the project was finished (Griffin to Tengan, personal communication 2000). In reflecting on his own withdrawal from Hawaiian issues, Howard commented, "When the Hawaiian revitalization started in earnest, I really decided to withdraw from being an active participant because I thought the leadership was there; I thought it was better for Hawaiians to be taking that initiative, though I was always prepared to be a resource if possible" (personal communication to Tengan I999). Here also departure (the ability of a researcher to "leave" or "retire" from the field [in both senses, the "field" as place of fieldwork and as area of study] indexes the boundaries of insider-outsider, researcherresearched, anthropologist-native, and haole-Kanaka. Such options are less available to indigenous researchers working in home societies who are more likely to retain a lifelong connection to places studied.

Howard's comment also shows that anthropologists in Hawai'i were aware of changes in the context of their work, brought about by the rise of the counterhegemonic discourse of " iwi decolonization, revitalization, and self-determination. The field imagined as pacific was increasingly turbulent. Ben Finney's experience on the Hawaiian voyaging canoe $H k$ $l e^{6} a$ in 1979 was emblematic of the changing relationship between anthropology and its subject (Finney 1999). Interestingly, in Finney's case, travel was the field rather than a means to get to the field. On the one hand, this departure from a reified concept of bounded culture may be one reason why Finney's work on voyaging has found lines of support and collaboration with " iwi scholars. On the other hand, the attraction may also stem from the significance of the canoe as a symbol of imagined pure spaces untouched by European exploration and colonization. Whatever the case, tensions between uses of the $H k l e^{6} a$ for scientific investigation and for cultural reclamation and resistance remain. Physical confrontations between Kanaka ' iwi and anthropologists in the early voyages served as a caution to future researchers who would believe that cultural knowledge practices in Hawai'i could be separated from indigenous struggles. This was further enunciated in moves to establish ethnic studies at the university in the early I970s and Hawaiian studies in the I980s. Both departments were created out of struggles to establish a Hawaiian (and "local" in the case of ethnic studies) voice within the university. In 
contrast with anthropology, both departments were explicitly concerned with empowering Kanaka' iwi (Aoude I999; H Trask I999, I 85-I86).

By this time a number of anthropologists in Hawai'i were cognizant of Hawaiian issues and began to make active contributions to the Hawaiian community as allies in their struggles. Finney's role in the development of the Polynesian Voyaging Society and the $H k l e^{6} a$ is acknowledged and appreciated by many Kanaka ' iwi today. Stephen Boggs was involved in the creation of the ethnic studies department and has been personally involved in sovereignty struggles (as was his graduate student Karen Watson-Gegeo, who earned her PhD in the department and taught for a numbers of years in the English as a second language department). Marion Kelly, at the Bishop Museum for many years and recently retired from ethnic studies, has made invaluable contributions through her ethnohistorical studies of land tenure and has been outspoken in her advocacy for Hawaiian rights (Kelly I956).

Despite the collaborative posture taken by some anthropologists at the university, the oppositional discourse of the Kanaka ' iwi activists and scholars has consistently opposed (or ignored) the discourse of anthropology, characterized as a haole (white, outsider) enterprise. Jocelyn Linnekin, a student of Marshall Sahlins, replaced Boggs on his retirement in 1983. Her own research followed paths of anthropological travel as she carried out intensive fieldwork in a rural Hawaiian village (Ke'anae, Maui) in I974 and I975. Linnekin's work attempted to demystify the "invented" traditions propounded by anthropologists and Hawaiian nationalists as "authentic" (I983; I992). Not surprisingly, this line of theorizing invoked repeated challenges from Kanaka " iwi (discussed later). As Native resistance to colonization grew outside the university, so it began to flourish within the academy, in fields that might be characterized as engaged cultural criticism. We conclude this brief history of anthropology at the University of Hawai'i by noting that the boundaries of outsiderness-reified in so much anthropological fieldwork-were now ironically policed by the same Natives formerly bound as its object.

\section{Outside or Inside: Anthropologist or Native}

Anthropology's valorization of outsiderness as a strategy for culture learning, seen as a core value from inside the discipline, is often seen by others as evidence of separation and detachment, of separate values and interests. Given the palpable legacy of power differentials between natives and nonnatives in a region with a long and present colonial history, it should not 
be surprising that "separate" is often read as divergent and conflicting. In the present era of decolonization, when the interests of foreigner and native are closely scrutinized by indigenous scholars concerned to critically unpack the (cultural) mechanisms of domination, "separate" easily implies "antagonistic."

As noted by Hau'ofa in his article cited at the outset of this paper (1975), this state of affairs is reinforced by the relative absence of native anthropologists who might otherwise complicate the dichotomous opposition of native versus anthropology. During the late-twentieth century, as increasing numbers of Islanders have pursued higher education, relatively few have entered or completed anthropology degrees. The absence of Pacific Islanders in the halls of the academy in the postwar era, when American anthropology was expanding rapidly, is remarkable.

Looking across the Pacific, there are only modest variations in this picture of absence. Even though we are presently in a moment of rapid change regarding the demography of Pacific Islanders in doctoral programs, the situation throughout the Pacific is similar to that of the UH program. At the University of Auckland, discounting degrees in archaeology or linguistics, only two $\mathrm{M}$ ori and one Pacific Islander have been awarded PhDs, although several are currently enrolled. In addition, two $\mathrm{M}$ ori and one Pacific Islander have completed MAs and gone on to do PhDs elsewhere since the founding of the department.

Among the small number of Pacific Islanders who have obtained graduate degrees in anthropology and now ply their trade, there are noticeable differences across subregions in the Pacific. In Papua New Guinea, host to legions of expatriate anthropologists over the years, the discipline has attracted both criticism and interest among indigenous scholars. ${ }^{12}$ At least three Papua New Guineans currently hold doctoral degrees in anthropology and occupy leadership positions in the nation's cultural and educational institutions. ${ }^{13}$ Others are currently pursuing graduate degrees in anthropology in Australia and elsewhere. ${ }^{14}$

The experience at the University of Hawai' $i$ is particularly telling. Even though the university has the most extensive resources in Pacific Islands studies in the United States and has always had a strong concentration of faculty specializing in Pacific studies, no native Islanders, and only one Native Hawaiian, have been awarded a doctoral degree in anthropology to date (although several are currently enrolled). And the numbers of master's degrees are similarly small. The late Kauraka Kauraka-for many years government anthropologist in the Cook Islands-received his MA from the department, as did Sergio Rapu of Rapa Nui (in archaeology). 
Clearly, many factors contribute to the absence of Pacific Islanders in the ranks of professional anthropology. However, despite the small numbers of Pacific Islanders pursuing graduate degrees in anthropology at the University of Hawai' $i$, the fields of political science, history, and American studies have graduated a number of Pacific Islander PhDs, all of whom have worked in their own societies on topics that would fit easily within the scope of cultural anthropology. Furthermore, the master's program in Pacific Islands studies has been a significant locus of indigenous scholarship, graduating significant numbers of Pacific Islanders and, more recently, ' iwi students graduating with bachelor's degrees in Hawaiian studies.

We argue that anthropology's self-identification as "outsider" has played a significant role in discouraging Islanders from pursuing careers in anthropology. Whereas the discipline has historically urged students to venture beyond their own cultures, most Pacific Island students come to anthropology with a strong interest in working in and contributing to their own communities. The motivations of those pursuing higher education from recently colonized communities, struggling to reclaim cultural pasts or to overcome the politics and economics of domination and dependency, are quite different from those of Europeans and Americans who came to the field in the mid-to-late-twentieth century with a strong commitment to cross-cultural work, even if that work ultimately fed back into domestic debates and movements.

When Tengan interviewed members of the UH anthropology department about the absence of Kanaka ' iwi in the program, numerous explanations were offered. Some faculty members mentioned problems that might discourage anyone from entering the field, such as shortage of jobs (Graves I999; Griffin to Tengan, personal communication I999) or practical relevance (Boggs I999). Kanaka ' iwi currently enrolled in the program tended to raise issues of disciplinary identity and practice, especially issues of boundary crossing and the contradictions of native anthropology. For example, K haunani Cachola-Abad, a recent " iwi PhD in archaeology ${ }^{15}$ pointed out that when Hawaiians want to learn about Hawaiian culture they go to Hawaiian sources, such as h lau hula (hula schools; Cachola-Abad to Tengan, personal communication I999). She also commented that Hawaiians generally see anthropology as the study of strange and exotic "others," a topic of far less interest than learning about their own ancestral culture.

Lynette Hi'ilani Cruz, an " iwi PhD candidate in cultural anthropology who received her MA in 1990 and subsequently pursued part-time 
teaching and community work, ${ }^{16}$ has struggled in part because she finds much of anthropological discourse alienating. ${ }^{17}$ In an email, Cruz wrote that "the discipline is and always has been geared to maintaining separation between white EuroAmerican culture and ourselves" (Cruz to Tengan, personal communication I999). In her view, “anthropology seems to lack protocol ... folks going into the field automatically believe that their academic credentials give them the 'right' to access information about their subjects/objects of study" (Cruz to Tengan, personal communication 2000; compare Osorio I995). She explained her own choices about practicing as an anthropologist:

i never left hawai' $i$ to do fieldwork elsewhere ... i could not see myself being maha'o $i$ [rude, impertinent] in someone else's land, asking them questions designed to take away their power and their identity for the examination of others. . . . i stayed home to write about contemporary hawaiian culture and the sovereignty movement because i felt that my contribution, as an anthropologist, was to tell a story about us as a people keeping ourselves intact in a global economy. ... . i don't really care about ... anthropological thinking unless it helps people to see clearly the power imbalances and gives them hope that things can change for the better. (Cruz to Tengan, personal communication 1999)

These personal testimonies of dissonance are nested in larger structures of difference and dominance, frequently coded in the language of race. When Tengan entered the program in 1998 , one of the most common reactions he received from Hawaiian friends was, "Wow, you know they're racist against Hawaiians?" The (largely undeserved) distinction of being labeled one of the university's most racist departments is particularly critical given that the university as a whole has been called "the last plantation" (Kelly to Tengan, personal communication I999).

Another line of questioning directed at Tengan was, "So what do you do with a degree in anthropology? Dig up bones? Teach? What?" These queries not only question the economic viability of pursuing such a career, but they point to underlying definitions of the enterprise itself. While cultural anthropologists may tire of references to bones in popular conceptions of the field, such conceptions are relevant to disciplinary identity and practice. Di Leonardo argued that the various (mis)conceptions of anthropology conjured up in the public sphere indicate roles the discipline plays in larger "structures of feeling" used to imagine America $(1998,32)$. She quoted Fabian to the effect that " $[\mathrm{w}]$ hen popular opinion identifies all 
anthropologists as handlers of bones and stones, it is not in error; it grasps the essential role of anthropology as a provider of temporal distance" ( 1983,30 , cited in di Leonardo I998, 30).

Anthropology's contributions to the American imaginary work to reaffirm or reinscribe its own professional identity as one forged in difference - difference reinforced by the opposition of anthropologist and native. Ben Finney's observations about the reception of anthropology among undergraduates at the University of Hawai'i are relevant here. Finney noted that, in contrast to universities in the continental United States, anthropology has never been a very popular subject here. He suggested that its "appeal for white American middle class as exotica" has never found much receptivity on a campus as ethnically diverse as those of the University of Hawai'i, especially when constructions of difference are "peddled from white profs" (personal communication to Tengan, I999).

Given the political and discursive forces that converge in the disciplinary practices of cultural anthropology, it should not be surprising that Kanaka ' iwi have found it difficult to carve out a space to tell their own histories and stories and challenge culturally enforced structures of domination. Economic realities, popular (hegemonic) images, and the disciplinary policing of insider-outsider borders all make the path toward a doctorate in anthropology a formidable task for Kanaka " iwi.

\section{Mixing Voices}

As we stated at the outset, one of the developments calling attention to the boundaries of anthropological identity is the emergence of significant numbers of native activists and authors concerned with issues of culture, history, and politics. The arrival of indigenous scholars in the halls of the academy and in the pages of major books and journals is transforming disciplines, disciplinary boundaries, and the production of knowledge about indigenous societies. Given the historical self-identification of anthropologists as outsiders or "strangers" (eg, Agar I980), voices speaking from positions inside Pacific languages and cultures-whether native anthropologist or nonanthropological culture critic-inevitably complicate the conventional discourse of anthropology as authoritative outsider.

One of the most well known entanglements involves anthropological writings on the invention of tradition that have analyzed political and ideological uses of culture in native nationalist movements. Significantly, two of the most notorious cases involving published exchanges between 
anthropologists of "invented" traditions and their native (and nonnative) critics are located in the Pacific - in Aotearoa and Hawai' $i$, where struggles between colonized native communities and dominant settler populations are particularly acute (eg, Hanson I989; R Keesing 1989; H Trask I99I). We do not wish to belabor these exchanges, which have been extensively discussed in a wide variety of writings. However, we do want to note that the debate that followed was interesting precisely because it crossed disciplinary and professional boundaries. In the process, the point of these exchanges shifted from interest in theorizing cultural forms and practices to a struggle over authority and legitimacy (Lindstrom and White I995).

Consider Haunani-Kay Trask's response to Roger Keesing's article "Creating the Past: Custom and Identity in the Contemporary Pacific" published in this journal in I989. Trask, a political scientist and at the time director of the University of Hawai'i Center for Hawaiian Studies, also aimed her criticism at the work of Jocelyn Linnekin (Tobin 1994). Trask argued that not only had Keesing failed to do his homework, but that his article reflected a more pervasive (and perverse) politics of representation in which the things an anthropologist writes about Hawaiians have "more potential power than what Hawaiians write about themselves" (I99I, I66). "For Hawaiians, anthropologists in general (and Keesing in particular) are part of the colonizing horde because they seek to take away from us the power to define who and what we are, and how we should behave politically and culturally" ( I99I, I63).

What is striking about Trask's essay is the degree to which it casts anthropology as wholly separate from and counter to native interests. The binary opposition of "anthropologists" and "natives," set out in the article's title and in the alignment of anthropology with "the colonizing horde" is only possible in a world where the discipline has few tiessocial, political, or intellectual—to the communities it studies. Otherwise, such wholesale rejection would not be possible without more dissonance. We suggest that this kind of separation has been fostered by anthropology's mythos of otherness and related practices that intensify native wariness of research practices associated with the colonial past.

If professional identities and career paths index the history and fate of disciplines, the experience of the first Pacific Islander to do doctoral fieldwork in Papua New Guinea offers a telling case. Epeli Hau'ofa, born of Tongan missionary parents in Papua New Guinea, became one of the first Pacific Islanders to complete a doctorate in anthropology in $1975 .{ }^{18} \mathrm{Like}$ 
Wari Iamo, who did his fieldwork in California far from his home society, Hau'ofa did his dissertation work among the Mekeo people of Papua (I975b; I98I). Yet, right from the outset, Hau'ofa expressed discontent with the conventional discourse of ethnography. In the essay cited earlier (published in Oceania in 1975), he wrote that "after decades of anthropological field research in Melanesia we have come up only with pictures of people who fight, compete, trade, pay bride-prices, engage in rituals, invent cargo cults, copulate and sorcerise each other. There is hardly anything in our literature to indicate whether these people have any such sentiments as love, kindness, consideration, altruism and so on" (I975a, 286). In this essay, Hau'ofa wrote in the collective voice ("we") of the profession of anthropology. At one point, writing critically of dominant professional practices, he positioned himself, along with the field, as "outside" the communities studied (thinking, perhaps of his own outsiderness to the Mekeo communities where he conducted earlier research). Such rhetorical moves inscribe the complex and shifting politics of indigenous anthropology.

Over the next few years Hau'ofa branched out into new forms of fiction writing which he found less confining than social science (Farber I998, 62). As a faculty member at the University of the South Pacific, he soon established himself as one of the most important authors of fiction in the region, in the I980s producing two novels, Tales of the Tikongs and Kisses in the Nederends, that gained a wide regional reading and brought him a reputation as one of the leading writers in the Pacific. Moving from fiction back to theory and Pacific studies, Hau'ofa has more recently produced a series of influential essays about the conceptual underpinnings of Pacific area studies and the politics of history (I993; I998; 2000).

Hau'ofa's career is an example of the malleability of anthropological identity, moving from "straight" cross-cultural ethnography to fiction to cultural criticism. How do we label Hau'ofa? (He has been called a "former anthropologist.") Who are the "we" doing the labeling? How does the University of the South Pacific label him within its institutional structures? How does he label himself (not, lately, as an anthropologist)? While Hau'ofa is more well known than most Pacific scholars, his case is not exceptional. In the (post)colonial Pacific there are few indigenous scholars for whom disciplinary training, institutional location, research interests, and methods converge to produce an easy identification of disciplinary identity. The non (or anti-?) disciplinary posture of much work by native scholars parallels in some ways the discourse of cultural studies- 
with its self-conscious resistance to institutionalization, more comfortably defined in opposition to established disciplines than establishing its own identity as a bounded field of study.

The mix of fiction writing and cultural criticism evident in Hau'ofa's work is characteristic of much indigenous scholarship. The writings of Albert Wendt and Vilsoni Hereniko are two cases in point. Both combine works of fiction in the form of novels, plays, and screenplays with essays about cultural identity and the problematic relations between Pacific Island communities and western scholarship (eg, Hereniko 1994; Wendt I993). ${ }^{19}$

Inverting the trajectory of Hau'ofa from anthropologist to fiction writer, Hereniko has moved back and forth between literature, ethnography, and cultural criticism in ways that have attracted both praise and attack from anthropologists. To further confuse the issue of disciplinary identity, Hereniko has participated in meetings and publications of the Association for Social Anthropology in Oceania and was even elected to its board of directors in the I990s. Somewhat like Geertz's evaluation of Clifford's hybrid disciplinary identity, the malleability and ambiguity posed by these crossings have proven troubling enough that some have felt compelled to defend disciplinary boundaries.

Although Hereniko's dissertation was filed in a department of language and literature (University of the South Pacific), it offered a largely ethnographic and historical account of clowning practices in his home island of Rotuma, with comparative observations elsewhere in the Pacific. When the book resulting from this work was subsequently published in the Pacific Islands Monograph Series of the Center for Pacific Islands Studies and the University of Hawai'i Press (I995), it was reviewed in several anthropology journals. Writing in the American Ethnologist, Allan Hanson, an anthropologist well known for his work in Polynesia (and for one of the controversies on the "invention of tradition" among $\mathrm{M}$ ori), penned a distinctly critical review of the book. Hanson was disturbed particularly by Hereniko's unorthodox mixing of fiction, personal conjecture, and ethnographic observation. Noting that the book is "presented in something other than ethnography in the usual sense" Hanson observed that "where his analysis spills over the traditional boundaries of ethnography, it flows in the direction of an intuitive account" (Hanson I996, I99).

As with Geertz's review of Clifford, the crux of the matter for Hanson 
is the epistemology of insider-outsider knowledge: an epistemology tied to the politics of fieldwork as boundary crossing. The brunt of his criticism focused on Hereniko's challenge to the superiority of outsider ethnography. Whereas Hereniko argued for a distinctive dimension of understanding that follows from native speaker (and native culture) status, Hanson read this as claiming that "the full meaning of any culture can never be grasped by a researcher (or reader) who is not a member of that society" (1996, 200). Leaving aside the presumption that any form of knowledge could represent the "full meaning of a culture," Hanson further equated Hereniko's position with the solipsistic view that ultimately people can only understand themselves.

To compound the matter further, Hanson challenged Hereniko's status as an insider. When Hanson noted that Hereniko "is himself Rotuman," he added, "albeit of the expatriate variety. He left the island at I 6 for education in Fiji and Great Britain, and he currently teaches Pacific literature at the University of Hawai'i" ( I996, I99). Apparently, if travel abroad for education doesn't disqualify you from cultural status, then teaching at the University of Hawai'i is surely fatal. The absurdity of this position was noted in a response by Alan Howard, who has devoted years to studying Rotumans in Rotuma and elsewhere, when he observed that when Hereniko left Rotuma at sixteen, he moved to Suva, Fiji, “where there are more Rotumans than on the island of Rotuma itself" (I997, I9I; emphasis in original). For Hanson the operative metaphor for culture is that of an island, remote and bounded, requiring long-term, settled, localized fieldwork. As in Geertz's treatment of Clifford, Hanson's caricature of Hereniko suggests some kind of disciplinary panic concerned to preserve the sacred spaces of fieldwork and ethnography.

In contrast to the relative absence of indigenous anthropology in the Pacific, recent years have seen a virtual renaissance of fiction writing by authors such as Hau'ofa, Wendt, and Hereniko (Hereniko and Wilson I999) and of video production by a host of new filmmakers (see Ginsburg 1994; Du Puis 1998; Palatella 1998). Located primarily in the Polynesian Pacific (S moa, Tonga, $M$ ori, Hawai'i), island writers and filmmakers are rapidly gaining a world audience. Perhaps because they resonate well with indigenous practices of storytelling and dramatic performance, fiction writing, theater, and video are being adopted rapidly by island authors and artists, providing the means for them to gain a voice in the disciplined spheres of cultural representation. 


\section{Conclusion}

Critical and often funny commentaries by Pacific Island writers such as Hereniko offer insight into popular perceptions of anthropology in the Pacific, especially for the cosmopolitan and elite communities where such writings are often produced (Hereniko and Teaiwa 1993). To no one's surprise, they suggest that the discipline does not control its own destiny; that it is caught up in a discursive politics associated with colonial history and forces of globalization that are only dimly understood by its practitioners. Anthropology's ethos of fieldwork and "will to otherness" has combined with Native readings of western domination to lead island scholars away from anthropology and toward a variety of fields such as literature, history, politics, and area study. Yet, native scholars are entering the field in a small but steady flow. As they do, they contribute to its ongoing transformation, as do the provocations of interdisciplinary cultural studies. As anthropology reconceptualizes the objects of its research, devises new approaches to fieldwork, and otherwise engages in dialogue with a shifting range of interlocutors, the discipline is redefined, with yet indeterminate results.

The difficulty - and perhaps opportunity-is that none of these terms is fixed: not fieldwork, not anthropology, not indigenous culture, and not cultural studies. Despite the efforts of Clifford Geertz and Allan Hanson on the one hand, or native activists on the other, to police the borders, the borders remain unstable and contested. Much as anthropologists may wish to reproduce a vision of committed, honest work in faraway places, or native voices may speak of finally guarding and purifying indigenous communities, these possibilities remain contingent on specific historical and political conditions, caught up in wider forces of economic and cultural production. Yet these same unsettled conditions may also offer a way out of the disabling generalizations that have become commonplace in programmatic statements about the contested borders of anthropology, native studies, and cultural studies.

WE WOULD LIKE TO THANK a number of people who have read and commented on this paper and on two papers that preceded it: one by White on relations between anthropology and cultural studies in the Pacific given at the 1998 meetings of the American Anthropological Association and one by Tengan on the history of Hawaiian anthropology at the University of Hawai'i given at the World 
Indigenous Peoples Conference in Hilo, Hawai i in 1999. Both papers benefited from comments by participants in those symposia, as well as from participants at the conference on Native Pacific Cultural Studies on the Edge organized by Vicente Diaz and J K haulani Kauanui that is the basis for this special issue. We would like to thank particularly the organizer of the 1998 panel, Karen Kelsky, and discussants Wahneema Lubiano and Daniel Segal, as well as James Clifford and Yoshinobu Ota who provided useful comments on White's I998 paper. We are also grateful to all those who talked with Ty Tengan about the history and state of Hawaiian anthropology, especially Scott Kekuewa Kikiloi for continued discussion of issues raised here.

We are indebted to numerous colleagues for information about anthropology degrees awarded to Pacific Islanders, even as we note that our efforts in this direction remain partial and incomplete. We would like to thank Alan Howard for his memory about Pacific Islanders in the UH anthropology program; Judith Huntsman and Linda Tuhiwai Smith for information on M ori researchers; Kimberly Kibleng for Micronesian anthropologists; and Mark Busse, Lamont Lindstrom, and Stuart Kirsch on Papua New Guinea and Melanesia.

Finally, we want to acknowledge helpful comments on this paper by David Akin, Steven Boggs, Keith Camacho, Quetzil Castañeda, Ben Finney, Michael Graves, Vilsoni Hereniko, Sally Merry, Miriam Stark, Dominica Tolentino, Christine Yano, and, especially, Vince Diaz and K haulani Kauanui.

\section{Notes}

I By "native studies" we have in mind programs such as Hawaiian studies or $\mathrm{M}$ ori studies as well as less formally institutionalized practices such as work on indigenous societies carried out in ethnic studies and related fields. There is even wider latitude in the range and variety of work in cultural studies across its multiple locations and histories (Stratton and Ang 1996).

2 Because of our interest in this paper in sketching a genealogy of Pacific Islander writers in anthropology and related fields, we more often identify the national or ethnic background of indigenous authors than others (who in most instances may be assumed to be white and American or European). This implicit marking (or lack of marking) of racial dominance in the profession is an unfortunate consequence of the colonial legacy we seek to critique.

3 Various forces have colluded in the postwar Pacific to deter Pacific Islanders from entering the field of anthropology. As Crocombe noted in a published response to Hau'ofa's paper (1975a), the practical realities of employment opportunities for anthropologists in island nations and the priorities of island governments placed a higher value on other fields of study. 
4 See also Hymes 1972; Asad 1979; Fahim I982; Diaz 1989; Teaiwa I995.

5 Compare di Leonardo's argument that in myopically disregarding “America" anthropology has tended to overlook "its own specifically American history, most importantly its growth in conjunction with the rise to hegemony of the American imperial state" ( I998, I6).

6 Scott Michaelsen has described parallels for Native American authors who wrote and published ethnographic accounts of their own peoples (I999). Many of these "organic intellectuals" also had careers but worked with white anthropologists in roles as informants and "contributors" to mainstream publications.

7 See Kauanui (1998) for a discussion on how the racialization of Hawaiians, especially through the passing of the Hawaiian Homes Commission Act, has worked to dispossess " iwi of land entitlements.

8 Interestingly enough, at the same time as Keesing was in Moloka'i conducting interviews with homesteaders in the summer of I935, the Handys were traveling around the $\mathrm{Ka}^{\text {' }}$ district with Mary Kawena Pukui and conducting interviews with the $\mathrm{k}$ puna (elders) in her family. While the two anthropological projects and the motivations for conducting them followed different agendas, both reaffirmed the assumption that fieldwork is properly conducted by anthropologists traveling away from their homes to study the native "out" in the field (Clifford 1997).

9 Another factor that both consolidated and intensified research in the Pacific was the Tri-Institutional Program of Pacific Research (TRIPP) initiated by the University of Hawai'i, Bishop Museum, and Yale University in 1953 to address "problems of dependent peoples of the Pacific" (Luomala I969, 29). The TRIPP project further demonstrates the institutional links and larger research paradigms in which the UH anthropology department was implicated at the time.

Io A 1952 transmittal from the United States to the United Nations tellingly stated, "with the exception of certain provisions favoring Native Hawaiians in regard to land, there are no discriminatory laws. The dominant trend in race relations is in the direction of eliminating those forms of racial discrimination that do exist" (United Nations 1946-58, cited in M Trask I994, 80).

I I Researchers involved in the $\mathrm{N} n$ kuli research were drawn primarily from the fields of psychology and anthropology, including Steven Boggs, Robert Edgerton, Ronald Gallimore, Alan Howard, Douglas Price-Williams, and Roland Tharp. A closer look at relations among the disciplinary actors and models involved in Hawaiian research might give a more nuanced picture of how the assumptions and conventions of each discipline work to enshrine specific aspects of popular images of indigenous culture and society.

I 2 Even before the Mead-Freeman controversy erupted for S moa, the I984 film Anthropology on Trial: Papua New Guinea presented a documentary account of local criticism of foreign-dominated anthropology in the country. Attempting something of a balanced presentation, the film also portrayed the emergence of 
an indigenous anthropology, showing then graduate student Wari Iamo pursuing his degree at the University of California at Berkeley.

I 3 True to anthropological values, the one Papua New Guinean who has completed a doctoral program in the United States, Wari Iamo, did so on the basis of a project working cross-culturally in urban America (Iamo 1987). Iamo, who recently ran for parliament, has also been director of the National Research Institute. The second Papua New Guinean to obtain a PhD in anthropology, Jacob Simet, obtained his degree from Australian National University on the basis of a dissertation focused on his own society, the Tolai of New Britain. He is now director of the National Cultural Commission. Finally, Linus Digim'Rina, who also received his degree from Australian National University, is currently chair of the department of anthropology and sociology at the University of Papua New Guinea.

I4 Published work by these scholars deals with many of the same issues taken up in EuroAmerican anthropology: exchange practices, cultural or ethnic identity, nationalism, the impacts of transnational investment, development, and so forth (eg, Iamo and Simet 1998; Simet 1994). The difference, and this is reflected in the kinds of positions held by recent graduates, is that indigenous anthropologists in Papua New Guinea are generally working on social and economic policy issues of local and national interest. In a nation with the largest land mass in Oceania, three-fifths of the region's population, and the greatest proliferation of linguistic and cultural groups anywhere in the world, there is no shortage of issues for applied social and cultural research. Thus, Jacob Simet, as head of the country's National Cultural Commission, is currently working on the development of national cultural policy and related issues such as cultural tourism.

A critical point in all this is that these scholars are located in a newly independent nation where they have been able to move into positions of authority in its educational and research institutions-a situation quite similar to Solomon Islands and Vanuatu. The absence of significant European or nonindigenous populations in any of these countries and of the formation of diasporic communities outside national boundaries constitutes a significant contrast with many other Pacific nations. Having said this, PNG anthropologists, despite their ability to work according to local priorities (however tied up with interests of the state), have also offered their own critiques of the discipline and its colonial legacy (see Gegeo I994; also Iamo I992; Iamo and Simet 1998).

I5 In fall 2000 Cachola-Abad became the first " iwi to graduate with a $\mathrm{PhD}$ from the department. She is the first recipient of the American Anthropological Association's Minority Dissertation Fellowship (1999-2000) and wrote her thesis using Hawaiian oral histories to test or refute older theories of migration.

I6 She returned to work full-time to help put her children through school. In addition to her community work, Cruz has taught classes in ethnic studies and peace studies at the University of Hawai'i, as well as a course on "Sovereignty 
Process and the Sacred Community" in anthropology at Hawai'i Pacific University.

I7 Equally discouraging are the posts she receives on her sovereignty listserve that frequently highlight the role of anthropologists in the neocolonial struggles of indigenous people.

I 8 Interestingly, Clifford has also made reference to Hau'ofa as a diasporic intellectual whose routes of research and publication depart from anything like conventional anthropology or area study (Clifford I997, 79).

I9 Albert Wendt, professor of English at the University of Auckland, is perhaps the most well known and widely read Pacific Island author today. Others might point to $\mathrm{M}$ ori author Keri Hulme, winner of the Booker Prize for The Bone People, or perhaps Alan Duff for his Once Were Warriors. Wendt's books Leaves of the Banyan Tree, Sons for the Return Home, P uliuli, Flying Fox in a Freedom Tree, Black Rainbow, and Ola command an international audience. Added to this, he has produced a number of commentaries on the colonial legacies of Pacific studies. In "Novelists and Historians and the Art of Remembering" (1987), Wendt criticized historians who work without a deep grounding in indigenous language and culture-a critique that could be read as a plea for more anthropological-style methods requiring depth of knowledge and long-term engagement. More recently, he has turned his attention to investigating the cultural underpinnings of literary theory and criticism (I999).

\section{References}

Agar, Michael $\mathrm{H}$

I980 The Professional Stranger: An Informal Introduction to Ethnography. New York: Academic Press.

Aoude, Ibrahim G, editor

1999 The Ethnic Studies Story: Politics and Social Movements in Hawai'i. Special issue of Social Process in Hawai'i 39 . Honolulu: University of Hawai'i Press.

Asad, Talal

I979 Anthropology and the Colonial Encounter. In Politics of Anthropology: From Colonialism and Sexism Toward a View from Below, edited by Gerritt Huizer and Bruce Manheim, 9-I9. The Hague: Mouton.

Beaglehole, Earnest

I937 Some Modern Hawaiians. Honolulu: University of Hawai'i Research Publications I9.

\section{Boggs, Stephen T}

I985 Speaking, Relating, and Learning: A Study of Hawaiian Children at Home and at School. Norwood: Ablex Publishing Corporation.

I999 Comments on "To Salvage Anthropology in Hawai'i," a paper pre- 
sented by Ty K wika Tengan at World Indigenous Peoples' Conference on Education, Hilo, August.

Chen, Kuan-Hsing, editor

1998 Trajectories: Inter-Asia Cultural Studies. New York and London: Routledge.

Clifford, James

I997 Routes: Travel and Translation in the Late Twentieth Century World. Cambridge, mA: Harvard University Press.

I989 Notes on Travel and Theory. Inscriptions 5: Traveling Theories, Traveling Theorists. edited by James Clifford and Vivek Dhareshwar. http:// humwww.ucsc.edu/DivWeb/CultStudies/PUBS/Inscriptions/insc_top I.html

Crocombe, Ron

1975 Anthropology, Anthropologists and Pacific Islanders: A Reply to Dr Hau'ofa. Discussion Paper I I. Port Moresby: Institute of Papua New Guinea Studies.

Di Leonardo, Micaela

1998 Exotics at Home: Anthropologies, Others, American Modernity. Chicago: University of Chicago Press.

Diaz, Vicente

I995 Simply Chamorro: Telling Tales of Demise and Survival in Guam. The Contemporary Pacific 6:29-58.

I989 Restless $\mathrm{Na}(\mathrm{rra})$ tives. Inscriptions 5. Traveling Theories, Traveling Theorists. edited by James Clifford and Vivek Dhareshwar. http://hum www.ucsc.edu/DivWeb/CultStudies/PUBS/Inscriptions/insc_topr.html Dominguez, Virginia

1996 Disciplining Anthropology. In Disciplinarity and Dissent in Cultural Studies, edited by C Nelson, 37-6r. London and New York: Routledge.

Du Puis, Reshela

1998 Hawaiian Documentary Videos as Political Tools. In The Garland Encyclopedia of World Music, volume 9: Australia and the Pacific Islands, edited by Adrienne Kaeppler and Jacob Love, 22 I-223. New York: Garland Publishing.

Fabian, Johannes

I983 Time and the Other: How Anthropology Makes Its Object. New York: Columbia University Press.

Fahim, Hussein, editor

I982 Indigenous Anthropology in Non-Western Countries. Durham, NC: Carolina Academic Press.

Farber, Thomas

I998 The Face of the Deep. San Francisco: Mercury House. 
Ferguson, Kathy, and Phyllis Turnbull

I998 Ob Say, Can You See? The Semiotics of the Military in Hawai'i. Minneapolis, MN: University of Minnesota Press.

Finney, Ben

I999 The Sin at Awarua. The Contemporary Pacific I I: I-33.

Foster, Robert

I999 Melanesian Anthropology in an Era of Globalization. The Contemporary Pacific II:I3 8-I 59.

Freeman, Derek

I983 Margaret Mead and Samoa: The Making and Unmaking of an Anthropological Myth. Cambridge, MA: Harvard University Press.

Gallimore, Ronald, and Alan Howard, editors

1968 Studies in a Hawaiian Community: Na Makamaka o Nanakuli. Pacific Anrthropological Records I. Honolulu: Bishop Museum Press.

Gegeo, David

1994 Kastom Nao Stretem Iumi: Views from Kwara'ae on Cultural Policy in Melanesia. In Culture, Kastom, Tradition: Developing Cultural Policy in Melanesia, edited by L Lindstrom and G White, 43-54. Suva, Fiji: Institute of Pacific Studies, University of the South Pacific.

$200 \mathrm{I}(\mathrm{Re})$ visioning Knowledge Transformation in the Pacific: A Response to Subramani's “The Oceanic Imaginary.” The Contemporary Pacific I3: I76-I 8I.

Ginsburg, Faye

I994 Embedded Aesthetics: Creating a Discursive Space for Indigenous Media. Cultural Anthropology 9 (3): 365-382.

Graves, Michael

I999 Comments on "To Salvage Anthropology in Hawai' i," paper presented by Ty K wika Tengan at World Indigenous Peoples' Conference on Education, August.

Hall, Stuart

1992 Cultural Studies and Its Theoretical Legacies. In Cultural Studies, edited by L Grossberg, C Nelson, and P Treichler, 277-286. New York and London: Routledge.

Handler, Richard

1993 Anthropology Is Dead! Long Live Anthropology! American Anthropologist 95 (4): 99I-999.

Handy, E S Craighill, and Elizabeth Green Handy

1972 Native Planters in Old Hawaii: Their Life, Lore, and Environment, with the collaboration of Mary Kawena Pukui. Bishop Museum Bulletin 233. Honolulu: Bishop Museum Press.

Handy, E S Craighill, and Mary Kawena Pukui

I935 Ohana, the Dispersed Community of Kanaka. Honolulu: Institute of Pacific Relations. University of Hawai'i Library. 
1972 The Polynesian Family System of $\mathrm{Ka}^{\star}$, Hawai ${ }^{\circ}$. Rutland, vт: Charles E Tuttle.

Handy, E S Craighill, Mary Kawena Pukui, and Katherine Livermore

1934 Outline of Hawaiian Physical Therapeutics. Bishop Museum Bulletin I26. Honolulu: Bishop Museum Press.

Hanlon, David

I994 Publishing and the Art of Navigation in the Contemporary Pacific. Paper presented at Internationalizing Cultural Studies Conference, East-West Center, Honolulu.

Hanson, F Allan

I989 The Making of the Maori: Culture Invention and Its Logic. American Anthropologist 91:890-902.

I996 Review of Woven Gods: Clowns and Power in Rotuma, by Vilsoni Hereniko. In American Ethnologist 23 (I): 199-200.

Harrison, Faye V, editor

1997 Decolonizing Anthropology: Moving Further toward an Anthropology for Liberation. Second edition. Arlington, va: Association of Black Anthropologists, American Anthropological Association. First edition, I99I.

Hau'ofa, Epeli

1975a Anthropology and Pacific Islanders. Oceania 45:283-289.

I975b Mekeo: A Study of a Papua New Guinea Society. PhD thesis, Department of Anthropology, Australian National University, Canberra.

I98 I Mekeo: Inequality and Ambivalence in a Village Society. Canberra: Australian National University Press.

1993 Our Sea of Islands. In A New Oceania: Rediscovering Our Sea of Islands, edited by Eric Waddell, Vijay Naidu, and Epeli Hau'ofa, 2-I6. Suva, Fiji: University of the South Pacific.

I998 The Ocean in Us. The Contemporary Pacific I0:392-4Io.

2000 Pasts to Remember. In Pacific Pasts, edited by Rob Borofsky, 453-47I. Honolulu: University of Hawai'i Press.

Heke, Ihirangi, and Michael P J Reilly

I995 Identity and Authority: A Dialogue on Maori History. In Work in Flux, edited by Emma Greenwood, Klaus Neumann, and Andrew Satori, 2OI-222. Melbourne: University of Melbourne History Department.

Hereniko, Vilsoni

I994 Representations of Cultural Identities. In Tides of History: The Pacific Islands in the Twentieth Century, edited by K R Howe, Robert C Kiste, and Brij V Lal. Honolulu: University of Hawai'i Press.

I995 Woven Gods: Female Clowns and Power in Rotuma. Pacific Islands Monograph Series I 2. Honolulu: Center for Pacific Islands Studies and University of Hawai'i Press. 
Hereniko, Vilsoni, and Teresia Teaiwa

I993 Last Virgin in Paradise. Suva, Fiji: Mana Publications.

Hereniko, Vilsoni, and Rob Wilson, editors

1999 Inside Out: Literature, Cultural Politics and Identity in the New Pacific. Lanham, MD: Rowman \& Littlefield.

Hiroa, Te Rangi (Sir Peter Buck)

I945 An Introduction to Polynesian Anthropology. Bishop Museum Bulletin I 87. Honolulu: Bishop Museum Press.

Howard, Alan

1974 Ain't No Big Thing: Coping Strategies in a Hawaiian-American Community. Honolulu: University Press of Hawai'i.

I997 Hanson's Review of Woven Gods. American Ethnologist 24 (I): I9I-I92.

I999 Rethinking the Role of Universities at the Millennium. Talk presented in honor of the inauguration of Rose Tseng as Chancellor, University of Hawai'i, Hilo.

Hymes, Dell H

1972 Reinventing Anthropology. Pantheon Antitextbooks. New York: Pantheon Books.

Iamo, Wari

I987 In Search of Justice and Shelter in Mix-town, USA. PhD dissertation, anthropology, University of California, Berkeley.

I992 The Stigma of New Guinea: Reflections on Anthropology and Anthropologists. In Confronting the Margaret Mead Legacy: Scholarship, Empire and the South Pacific, edited by L Foerstel and A Gilliam, I I7-I 32. Philadelphia: Temple University Press.

Iamo, Wari, and Jacob Simet

I998 Cultural Diversity and Identity in Papua New Guinea: A Second Look. In From Beijing to Port Moresby: The Politics of National Identity in Cultural Policies, edited by V Dominguez and D Wu. Amsterdam: Gordon \& Breach.

Jones, Delmos

1970 Towards a Native Anthropology. Human Organization 29 (4):25I-259. Reprinted in Anthropology for the Nineties, edited by Johnetta B Cole, 30-4I.

Kauanui, J K haulani

I998 "For Get" Hawaiian Entitlement: Configurations of Land, "Blood," and Americanization in the Hawaiian Homes Commission Act of 1920. Social Text 59 (Summer): I23.

Keesing, Felix

I936 Hawaiian Homesteading on Molokai. Research Publication I2. Honolulu: University of Hawai'i. 
Keesing, Roger

I989 Creating the Past: Custom and Identity in the Contemporary Pacific. The Contemporary Pacific I:I9-42.

Kelly, Marion

I956 Changes in Land Tenure in Hawai'i, I778-I 850. MA thesis, Pacific Islands Studies, University of Hawai'i, Honolulu.

Kiste, Robert C, and Mac Marshall, editors

I999 American Anthropology in Micronesia: An Assessment. Honolulu: University of Hawai'i Press.

Knauft, Bruce M

1999 From Primitive to Postcolonial in Melanesia and Anthropology. Ann Arbor: University of Michigan Press.

Lewis, Herbert $S$

I999 The Misrepresentation of Anthropology and Its Consequences. American Anthropologist I00 (3): 7 I6-73I.

Lindstrom, Lamont, and Geoffrey White

1995 Anthropology's New Cargo: Future Horizons. Ethnology 34 (3): 2OI-2IO.

Linnekin, Jocelyn

I983 Defining Tradition: Variations on the Hawaiian Identity. American Ethnologist $\mathrm{IO}: 24 \mathrm{I}-252$.

I992 On the Theory and Politics of Cultural Construction in the Pacific. Oceania 62:249-263.

Luomala, Katharine

I969 Imponderabilia for a History of Anthropology at University of Hawai' $i$, 1922-I946. News from the Pacific I9:I-32.

Mahina, 'Okusitino

I999 Theory and Practice in Anthropology: Pacific Anthropology and Pacific Islanders. Social Analysis 43:4 I.

Marcus, George E

I995 Ethnography in/of the World System: The Emergence of Multi-Sited Ethnography. Annual Review of Anthropology 24:95-I I7.

Michaelsen, Scott

I999 The Limits of Multiculturalism: Interrogating the Origins of American Anthropology. Minneapolis: University of Minnesota Press.

Motzaffi-Haller, Pnina

I997 Writing Birthright: On Native Anthropologists and the Politics of Representation. In Auto/Ethnography: Rewriting the Self and the Social, edited by Deborah E Reed-Danahay, 195-222. Oxford and New York: Berg.

Narayan, Kirin

1993 How Native is a "Native" Anthropologist? American Anthropologist 95:67I-686. 
Nelson, Cary

I994 Always Already Cultural Studies: Academic Conferences and a Manifesto. In English Studies/Culture Studies, edited by I Smithson and N Ruff, I9I-205. Urbana: University of Illinois Press.

Nugent, Stephen, and Cris Shore

I997 Anthropology and Cultural Studies. Anthropology, Culture, and Society Series. London and Chicago: Pluto Press.

Okamura, Jonathan

I998 The Illusion of Paradise: Privileging Multiculturalism in Hawai'i. In Making Majorities, edited by D Gladney, 264-284. Stanford: Stanford University Press.

Osorio, Jonathan Kamakawiwo'ole

I995 Protecting Our Thoughts. Lei o Ka Lanakila (Spring): 2-3.

Palatella, John

I998 Pictures of Us: Are Native Videomakers Putting Anthropologists Out of Business? Lingua Franca 8 (5): 50-57.

Peace, Ade

1998 Anthropology and Cultural Studies. Special issue of The Australian Journal of Anthropology 9 (3).

Perez, Michael P

I997 The Dialectic of Indigenous Identity in the Wake of Colonialism: The Case of Chamorros of Guam. PhD dissertation, Department of Sociology, University of California at Riverside.

Quigg, Agnes

I987 History of the Pacific Islands Studies Program at the University of Hawai' $i$, I950-I986. Working Paper. Honolulu: University of Hawai'i Center for Pacific Islands Studies.

Rafael, Vicente L

I994 The Cultures of Area Studies in the United States. Social Text (Winter): 9I-III.

Said, Edward W

I979 Orientalism. New York: Vintage.

Simet, Jacob L

I994 Tolai Concepts of Culture. In Culture, Kastom, Tradition: Developing Cultural Policy in Melanesia, edited by L Lindstrom and G White. Suva, Fiji: Institute of Pacific Studies, University of the South Pacific.

Smith, Linda Tuhiwai

I999 Decolonizing Methodologies: Research and Indigenous Peoples. London and New York: Zed Books.

Souder, Laura, and Robert Underwood

I987 Chamorro Self-Determination. Mangilão: Guam: Micronesian Area Research Center and Chamorro Studies Association. 
Spate, O H K

I963 Islands and Men. In Man's Place in the Island Ecosystem: A Symposium, edited by F R Fosberg. Honolulu: Bishop Museum Press.

Stratton, Jon, and Ien Ang

I996 On the Impossibility of a Global Cultural Studies: "British" Cultural Studies in an "International" Frame. In Critical Dialogues, edited by K-H Chen and D Morley, 36I-39I. London and New York: Routledge.

Teaiwa, Teresia $\mathrm{K}$

1992 Microwomen: US Colonialism and Micronesian Women Activists. In Pacific History: Papers from the 8th Pacific History Association Conference, edited by Don Rubinstein, I25-I42. Mangilão: Micronesian Area Research Center and University of Guam Press.

I995 Scholarship from a Lazy Native. In Work in Flux, edited by Emma Greenwood, Klaus Neumann, and Andrew Satori, 32-56. Melbourne: University of Melbourne History Department.

Tierney, Patrick

2000 Darkness in Eldorado: How Scientists and Journalists Devastated the Amazon. New York: Norton.

Tobin, Jeffrey

1994 Cultural Construction and Native Nationalism: Report from the Hawaiian Front. In Asia/Pacific as Space of Cultural Production. Special issue of Boundary 2, edited by R Wilson and A Dirlik, II I-I33. Durham, NC and London: Duke University Press.

Trask, Haunani-Kay

I99I Natives and Anthropologists: The Colonial Struggle. The Contemporary Pacific 3:1 59-I67.

I999 From a Native Daughter: Colonialism and Sovereignty in Hawai' ${ }^{i}$. Revised edition. Honolulu: University of Hawai'i Press.

Trask, Mililani B

I994 The Politics of Oppression. In Hawai i: Return to Nationhood, edited by U Hasager and J Friedman, 7I-87. Document 75. Copenhagen: International Work Group for Indigenous Affairs.

Turner, Terence

I993 Anthropology and Multiculturalism: What is Anthropology that Multiculturalists Should Be Mindful of It? Cultural Anthropology 8 (4): 4II-429.

United Nations

I946-I958 Summaries and Analysis of Information Transmitted to the Secretary General. Pacific Territories, Hawai'i.

Wendt, Albert

I987 Novelists and Historians and the Art of Remembering. In Class and 
Culture in the South Pacific, edited by A Hooper, S Britton, R Crocombe, J Huntsman, and C Macpherson, 78-9I. Suva, Fiji: University of the South Pacific.

1993 Towards a New Oceania. In Readings in Pacific Literature, edited by Paul Sharrad, 7I-87. Wollongong: New Literatures Research Center, University of Wollongong.

1999 Afterword: Tatauing the Post-Colonial Body. In Inside Out: Literature, Cultural Politics and Identity in the New Pacific, edited by R Wilson and V Hereniko, 399-4I 2. Lanham, MD: Rowman \& Littlefield.

\section{Abstract}

In this paper we look at relations between anthropology, cultural studies, and native studies on the basis of their practice in the Pacific, focusing particularly on the history of anthropology at the University of Hawai'i. We draw attention to the absence of Pacific Islanders and, specifically, of Hawaiians as authors, agents, and practitioners of anthropology. Having noted these absences, we probe disciplinary practices that (re)produce boundaries of inside-out, native-other, representer-represented in Pacific scholarship. In particular, we examine ways in which fieldwork as both ideology and practice enforces separation between anthropology and native studies. Another development calling attention to the boundaries of anthropological discourse is the emergence of significant numbers of native authors and activists concerned with issues of culture, history, and politics. In contrast to the relative absence of indigenous practitioners of anthropology in the Pacific, recent years have seen a virtual renaissance of fiction writing and video production by Pacific Islanders, creating new forms of cultural criticism akin to interdisciplinary cultural studies in other parts of the world. As anthropology reconceptualizes the objects of its research, devises new approaches to fieldwork, and otherwise engages in dialogue with a range of interlocutors, the discipline is being redefined with as yet indeterminate results.

KEYWORDS: anthropology, cultural studies, fieldwork, Hawai'i, representation 